\title{
The European Economic Crisis in a Global Context and its Originator
}

\author{
Dr. Ioannis N. Kallianiotis \\ Economics/Finance Department \\ The Arthur J. Kania School of Management \\ University of Scranton
}

\begin{abstract}
In this paper, the European economic crisis is discussed by examining chronologically the events that started in the U.S. (the originator) in August 2007 and due to globalization they continued in the highly indebted Euro-zone members. The common public policy and the common currency in Euro-area do not help the member-nations to improve their economies and overcome the recession because these countries are different and need each one its own policy and target interest rate. There were too many mistakes that led us to the latest financial crisis and authorities have to prevent these crises. The enormous debts in the U.S. and in the EU member-nations are unsustainable and new mixed public policies and regulations are needed to avoid similar negative effects in the future. Austerities and contractionary policies, during periods of recession (with negative growth of the real GDP and extremely high unemployment), are exactly the opposite of what the economies want and these anti-social policies are very suspicious for any thinking person. We have to go back to a value oriented socio-economic system, where humans will be in its center and core.
\end{abstract}

Key Words: Consumption, Saving, Interest Rates, Monetary Policy, Fiscal Policy

\section{INTRODUCTION}

The purpose of this work is to discuss the elements that caused the latest and current problems in the European economies, which started from the capitalistic U.S. and consequently was expanded to all economies of the world, due to the systemic risk that globalization has induced to the developed and controlled nations. Thus, this crisis is a crisis of capitalism (a man-made inferior philosophical system). A recent historical retrospect is used to consider the evolution of events in the EU and the EMU before the crisis. The global uncertainty had increased the price of gold (decreased the value of the dollar) and the U.S. debts and deficits had caused a depreciation of the dollar, which with the help of speculators had heightened the price of oil until the fall of 2014 and had created a commodity bubble. The deregulation in financial markets and institutions and the easy money policy by the Fed had increased lending, corruption, speculation, prices in financial and real assets (even in food) and had caused an enormous bubble, which some people (the world planners) burst in 2008 and created the worst financial crisis, followed by the latest most severe recession in modern economic history. The enslaved EU is copying the U.S. and fell in the same trap, which caused the European Economic crisis.

The moral, ethical, and political crisis in the western free-market (value-free) economies led them in deep recessions, enormous unemployment, annihilation of their wealth, complete distrust for the financial markets, a new cold war, an elevation of terrorism, and the millions of 
illegal immigrants and refugees that the West's foreign policy generated in Middle East and North Africa. We describe the sequence of events first and then the benefits (gains) and costs (losses) to society by considering some actions and policies, which affected the objective macroeconomic variables and caused them to deviate from the target ones. Then, we determine the factors affecting the objective variables of the economy (unemployment, prices, and real GDP) by taking into consideration policy variables (i.e., the overnight deposit rate, federal funds rate, taxes, government spending, austerities, Troika, etc.). European nations and their people face an absolutely uncertain future because they have lost their national currency, their central bank, their public policies, and their freedom of speech, their educational system, their objective history, their indigenous values, and their sovereignty. The powerless world governments and regulators are just inactively watching the events that we are all part and responsible (especially, the academic environment) for this irrational, interdependent, and complex world, which was designed and created for the control of the future generations.

The literature on the European economic crisis is huge. All academics, politicians, and media are talking and trying to analyze this unique phenomenon in economic history and to explain the anti-growth policies that authorities are using to perpetuate the crisis. Stiglitz [9] is criticizing the globalization due to the problems that is causing to the advanced economies. Kallianiotis [3] and [4] analysis the factors that have caused the overvaluation of the euro and its negative effects on the Euro-zone member-nations. Bullard, neely, and Wheelock [1] discuss the financial crisis and the new systemic risk that has affected the global economic system. Wessel [10] gives a very good chronological presentation of the global financial crisis. Kallianiotis [2] mentions that the common currency is worse than the fixed exchange rate for the countries that have adopted it. Rickards [5] is talking about the future collapse of the international monetary system. Sposi and Grossman [8] are referring to deindustrialization of the western nations and the redeployment of workers to low pay jobs. Williamson [11] criticizes the new monetary policy that is pursued by the U.S. Fed.

\section{RECENT HISTORICAL RETROSPECT}

Humanity has gone a long way for thousands of years and had reached a high point of social development, moral ethics, philosophy, democracy, civilization, and even was waiting for the "True God", who came five centuries later. Then, with the revealed Truth new hope appeared for the people, especially in the Eastern Roman (Byzantine, Medieval Greek) Empire and the entire Europe, the "Christendom". The development in Europe was enormous after the adoption of the ancient Greek moral philosophy, civilization, and reaching the industrial revolution; but, behind every good effort there are other powers with suspicious objectives. One of these objectives, the top one, is globalization (global control of all the nations), which started with the integration of the European nations, and because it succeeded (artificially) with the European Union, there will be no objections and oppositions from any other developing or underdeveloped nation. Of course, the plan is the opponents to be crashed to prevent "contagion" to other nations.

The EEC started in January 1, 1958 (with the Treaty of Rome signed on March 25, 1957) and continued with the EU in 1993, with the EMU in 1999, its central bank (ECB, in Frankfurt, Germany) in 1998, its institutions, its regulations and directives, its constitution (Treaty of Lisbon) without referenda in 2009, which was imposed undemocratically to poor Europeans with pressure on the controlled politicians of the 28 member-nations (they call them "states"). The fixed exchange rate was abandoned in March 1973 because it did not work and the EU chose something worse than the fixed exchange rate, the common currency in 2002 (the euro) for its completely different nations that was imposed forcefully (without the nations satisfying the Maastricht criteria) to 19 poor nations and their citizens, which caused the loss of 
competitiveness of these economies and they have to do "internal devaluations" to compete with the rest of the world. What a deceit, treason, and criminal decision by the Brussels and the politicians of the member-nations! The Euro-zone nations are and will be in trouble in the future, too, because they lost their central bank, their domestic currency, their public policies, their independence, their sovereignty, and their indigenous culture, values, and freedom. These nations became colonies of Brussels (actually, German protectorates).

Of course, if a nation is not independent, self-sufficient, free, democratic, and negotiates with its partners by compromising its values and paideia, soon will be in crisis and the crisis had started with its accession to EU, which appears as an economic crisis in 2008 developed in the U.S., another union of 50 states that is in trouble, as the 28 states in EU. But, the U.S. dollar, at the moment, as an international reserve currency and the Fed supplying these greenbacks (Fed's liabilities backed by government debt) in trillions to finance the government and private debts, the country was "saved" with an unemployment over $23 \%$ and a recession that is still going on. The financial market collapsed in the U.S. and this contagion effect was spread to all the financial markets in EU member-nations. The peak of this stock market bubble was on October 9, 2007 (DJIA was 14,164.53) and its trough on March 9, 2009 (DJIA was 6,547.05), a decline of $-7,617.48$ points or by the percentage of $-53.78 \%$, and with calendar days to bottom 517. Investors lost $\$ 18$ trillion from their wealth; it was distributed from the naïve investors to the hawk speculators. This is today's stock market; a casino that can destroy the entire real economy.

The U.S. economy had long been characterized by international imbalances in its current and capital accounts and enormous public and private debts that have to be financed heavily by foreign capital and by money printing (Fed's reserves). The quantitative easing of the Fed is something that we see for the first time in Economic history. The monetary base from $\$ 874.826$ billion $(9 / 10 / 2008)$ reached $\$ 4,139.322$ billion $(1 / 21 / 2015)$. Lately, the Fed signaled that it would keep rates near zero until the midyear 2015; but, they continue to postpone an increase in federal funds rate because there is no improvement in the economy. At the same time the country lost its agriculture and manufacturing and became a pure service economy that is very vulnerable to business cycles and has caused enormous unemployment, reduction in income, and destruction of the small cities, towns, and country side of the nation. Some strange economists believe that this ruin of the domestic main sectors of the economy (agricultural and industrial) is normal and they call this detrimental process as "structural transformation". This is exactly what some ignorant politicians (betrayers) imposed on Greece and made the country dependent on Germans. The ECB did not increase the monetary base, which has contributed to the deep recessions. It was €899.514 billion (September 2008) and became $€ 1,292.102$ billion (January 2015). This current European crisis proved that countries must have their own central bank and their own national currency, otherwise, the crisis will become permanent.

On October 3, 2008, a bailout package passed by the U.S. government, which provided $\$ 700$ billion to restore confidence in the economy. But the deregulated banks had made too many bad loans, which have created big holes in their balance sheets. Treasury Secretary, Paul Paulson, was buying up the bad assets and putting the risk onto American taxpayers, hoping that banks would use this money to restart lending, but some of this money was paid as dividends to their shareholders and bonuses to their executives. The taxpayers are the losers in our corrupted financial system and its institutions. The U.S. economy had been sustained by excessive borrowing for many years (with a total government and private sector debt, including contingent liability as of January 1,2009 of over $\$ 174.1$ trillion, $\$ 564,749$ per capita, $1,213 \%$ of GNP). Also, unemployment was increasing and personal income and consumption 
were falling. Exports were declining and the revenue for state, local, and federal government was diminishing. The confidence level of consumers and investors had reached the lowest level since the introduction of these indexes. All these contingencies were negatively affecting the financial sector of the economy, which is the only sector left to sustain production, growth, and employment for the U.S. economy. The number of jobs lost in EU28 were 25.91 million in 2013. Greece lost 1.364 million jobs, which became the biggest humanitarian crisis for the country. The worst crisis for a person is to be unemployed, for this reason we had thousands of suicides. The objective of the government, central bank, and the other authorities must be to prevent crises and maximize social welfare, but these policy makers and regulators have no power and consequently, have lost control of the market and of the entire socio-political-economic system.

The "irrational exuberance" that Euro-subsidies and low interest rate loans gave to Europeans, is over after three decades of wastefulness, greediness, briberies, frauds, lies, and corruption. But this was expected because the EU economies and their markets were too good to be true. We were living a big delusion and this deceit is over. The economic and social indicators reveal that even the U.S. from a moral, ethical, and just superpower is becoming less and less competitive and less friendly with the rest of the world. The European Union (the forced integration of 28 nations, without referenda), with its debt crises and the common currency, is the worst "innovation" in human history. It is a mixture of twenty eight nations without domestic public policies, without self-determination, without sovereignty, and of course, without any future. All these strange evolutions have increased the global uncertainty, have caused unemployment in EU and the U.S., have reduced competitiveness, and have augmented poverty, anxiety, and health problems (mental and physical) to their citizens. The free-market system with its new innovation, the globalization through integration of the nations, has failed and needs more government regulation, more independence and self-determination for the nations, and better corporate governance for the MNCs that led domestic firms to bankruptcy and people to permanent unemployment (misery). Governments had to bailout a corrupted financial system, even when the deficits and the national debts are astronomical. But, they had no other option, except to "rob responsible Americans [and Europeans] and pay the robbers of the financial market". Then, what are the social benefits? Why we need these global changes and "evolutions", which are against humanity? The latest financial crisis (with a combination of large failures, costly bailouts, deep recessions, and destruction of entire countries) might be able to change the perception of the social welfare effects of the thirty years of deregulation and the fifty years of European integration. The Fed was instructed by Congress in 1977 to aim at "maximum employment" and "stable prices", but it cares for price stability (Bernanke considers inflation target). The ECB does not have employment as its mandate. Even though, we have to continue to hope.

But, a question remains even today. Who is to blame for the latest financial crisis, the peculiar recession that it caused, and the continuation of the humanitarian crisis? The responsible parties must be the following:

1. Politicians, who joined the Euro-zone without a referendum.

2. Corrupted politicians, executives, lobbyists, governments, institutions, rating firms, etc., which acted against social interest.

3. Countries, who consume beyond their production ( ).

4. The U.S. and EU households, who have spent way beyond their means in recent years; they have to start saving.

5. The banks, who took the upside and left the downside to the taxpayers.

6. The monetary and fiscal authorities, who did not intervene in the markets.

7. The regulators, who extended homeownership to even those who could not afford it.

8. The market and the tax system, who tolerate and encourage high leverage. 
9. The rating firms with their subjective ratings.

10. The involvement of IMF in Euro-zone debt crisis and bailouts.

11. The ECB's low liquidity towards the member-nations.

12. The European integration that imposes the same policy on completely different nations.

13. The anti-growth austerity policies in periods of recession.

14. The EMU that restricted the public policy and sovereignty of the member-nations.

15. The globalization and the pseudo-leaders, who follow this new age inhumane servitude.

The wealth must be created through saving, ingenuity, entrepreneurship, hard work, a fair tax system, and moderation in spending (waste). Of course, many try to create wealth by extracting wealth from others through inflation, overpricing their products and services, due to inelastic demands, inside information, and market manipulation. This is not wealth creation, but wealth redistribution from the naïve citizens to the greedy and shrewd opportunists. For these reasons, markets have to be regulated. The global financial system is so complex that with each financial collapse the systemic risk is growing exponentially. The global system with all these derivatives (\$691 trillion with June 2014), which are a surprise to bankers and regulators, is on the knife-edge of collapse. If a catastrophe unfolds, it is too late to stop. Crises have to be prevented through regulations. It is a pity for a country as large and powerful as the United States to have lost its sovereignty and to have this enormous dependency on the corrupted markets and for the Euro-zone member-nations to have become protectorates of Brussels (Germany). The first priority of any sovereign, democratic, and advanced nation is the welfare of its citizens and not to satisfy the demands of the corrupted and inhumane markets and their institutions and those of the EU and the lenders (that must know the risk of lending). We are enslaved by the corrupted markets and this cannot continue because our well-being is in trouble.

The conflicting forces of our time are: East versus West, gold versus paper, state (nation) versus markets, peoples' dignity versus complete indifference, truth versus lie, citizens versus allies, nation versus the world, spiritual world versus secular world, knowledge versus ignorance, patriotism versus globalism, individuals versus businesses, justice versus injustice, wealthy versus poor, democracy versus tyranny, liberty versus slavery, values versus distain, respect of life versus refusal of life, respect versus disrespect, liberalism versus conservatism, capitalism versus socialism, agreement versus abruption, integration versus independence, and many other conflicts. But, the objective of any knowledgeable society (nation) today must be the welfare of the country and the perfection of its people, all the other goals are inferior and worthless.

The latest financial crisis had its origin at the corruption in governments and businesses, which affected the financial and the housing markets. And this anticipated financial crisis together with the high debts and prices of energy and food (due to our lack of production and dependency on imports) brought the economy to a deep recession. The failure of the unregulated large financial institutions increased the systematic (market) risk and harmed other financial firms and finally, the real sector of the economy and due to high positive correlation of the world economies from the globalization, the risk became global (systemic). Another important type of risk to the Euro-zone member-nations is the lack of public policy, lack of national currency to exercise trade policy, lack of public central bank to absorb the national debt and provide the liquidity to the banks, and the loss of national sovereignty.

The lack of liquidity has negative, especially, for Greece (where is used as a weapon of coercion and acceptance of the wrong policies imposed by the Troika), but rarely positive effects. One of the positive effects was that speculators using borrowed money were being forced out of the market. The problem with our speculators has been created with the margin requirements, 
which is only $50 \%$. To avoid this tremendous market risk, the margin requirements must be $100 \%$. Regulation T of the Federal Reserve Board has to be revised. Also, the SEC must prohibit the short-selling. The anti-trust laws must be imposed on every firm and industry. They cannot become giants and then, the Treasuries and the central banks have to bail them out with our money (tax payers' money). An increase oversight of the Treasuries and the central banks is needed, speculation must be curbed, and futures market has to be regulated because they affect the spot market with their outrageous scenarios and price manipulations. CEO salaries are provocative for our welfare and just societies; then, limits on executive pay are necessary. Transparency and accountability for mortgage-fraud or other greedy actions by executives is important for the public to start trusting the markets. Investment banks and exotic types of financial instruments must be regulated and the same must hold for all the other financial institutions.

\section{POLICY EFFECTIVENESS AND SOME POLITICAL CONSIDERATIONS TO PREVENT FUTURE CRISES}

A financial panic in the next several years is very probable; this can be caused by the rating firms, by the central banks' policies, by the international institutions, by derivatives exposure and bank interconnectedness, which may trigger a global liquidity crisis. But, there is no possibility that Greece's exit from Euro-zone can caused any global or European crisis, its economy is very small (2\% of the Euro-zone). These people (in Europe and the U.S.), which pretend that they worry and they care for Greece's exit from Euro-zone are lying because their objective is different; they want to terrorize the other nations that no one can go against globalization. Social disorder is also very probable during a new global financial crisis. Social disorder involves riots, strikes, sabotage, dysfunctions. It is distinct from social protest because disorder involves illegality, violence, and property destruction; which will be very risky for countries that carrying of arms is free, like in the U.S.A. But, the new "constructed" Ukraine crisis in Europe, the continuation of the cold war, together with the continuing EU austerities and wrong German and IMF policies, the Islamic State of Iraq and Syria (ISIS), the millions of illegal immigrants in Europe that the foreign policies of West created, which alter the European identity, pressure from the "allies" give very bad signals for the entire world.

Countries have to be independent democracies, self-sufficient (even exercising protectionism for their domestic industries), promoting first the primary sector (agriculture), second the secondary one (manufacture), and lastly the tertiary sector (services). An economy specializing only in services has no future. The country must produce more goods and services than are needed for domestic consumption and export the excess production. But, the persistence of the West on cold war put embargos, which affect negatively the economies of the small European nations. A nation has to have growth and zero unemployment, also, it has to have a high saving rate, too (25\% of the disposable income). The financial markets and the entire economy have to be controlled (regulated) and every firm must comply with the socially imposed constraints. The ultimate objective of a country is maximization of its social welfare (minimization of the loss to society). We need a worldwide governmental intervention to support and regulate the national banking systems. Central banks have to be public, supporting the public policies of the nation. Domestic public policies must deal with human beings and their welfare. Economic policies must have one objective; the prevention of future crises, as the one that the world and the EU experienced lately. The Theory of Finance has to change from now; the U.S. government securities are not risk-free anymore because governments are controlled by the markets (Mammon). Who gave this power to the rating firms to overturn (even though that we know it is wrong) our global financial system? The negative effects on the real economy and on peoples' lives are enormous. These existing financial markets, institutions, and policies have to be controlled by the governments of the sovereign nations; otherwise, they will generate very 
soon a global collapse and the worst civil unrest and destruction of the entire world, except if this is the objective.

The Fed actually can monetize any amount of debt the Treasury issues, up to the point of a collapse of confidence in the dollar. If national income can pay the interest on the debt, with enough left over to reduce total debt as a percentage of GDP, then the situation should remain stable. If there is not enough national income left over after the interest to reduce the debt as a percentage of GDP, and if this condition persists, then the U.S. will eventually go bankrupt. The same holds for all the EU member-nations and in trouble are those that are members of the EMU. The deficits are sustainable only when,

$$
\begin{aligned}
& (\dot{q}+\pi)-I>|T-G| \\
& (4 \%+1 \%)-2 \%>2 \%
\end{aligned}
$$

Where, = the growth of real output $(\mathrm{GDP}),=$ inflation, = the growth of nominal GDP, = borrowing (interest) cost (as a percentage of GDP), = taxes, = government spending, and = primary deficit (as a percentage of GDP).

The deficit is not sustainable if,

$$
\begin{aligned}
& (\dot{q}+\pi)-I<|T-G| \\
& (2 \%+1 \%)-2 \%<2 \%
\end{aligned}
$$

The above numerical example is showing an unsustainable condition. This shows the trend toward unsustainability. The key factors in primary deficit sustainability (PDS) are borrowing costs ( ), real output ( ), inflation ( ), taxes ( ), and government spending ( ). The best way to move toward sustainability is to increase real growth (the production of the nation). Another way is the one that (Troika) EU is using for its member-nations, improving debt sustainability by increasing taxes, which is absolutely wrong during periods of recessions or depressions. Also, if taxes are held steady and spending is cut, the primary deficit shrinks, but this policy is contractionary and does not stimulate an economy that is in recession. The central banks' policies can affect inflation ( ) and interest rate () cost of borrowing, which can affect the PDS and finally, the debt as a percentage of the GDP. In the absence of higher real growth, either politicians must reduce deficits or the central banks must produce inflation and reduce the cost of borrowing, with its excess supply of liquidity. But, for all these scenarios to work, the country must be independent, which means to stay out of the EMU.

Data on public and private debt and deficits, on economic performance, on unemployment, and the buildup of derivatives inside megabanks are readily available, but conventional economic models and economists do not want to see the truth; they follow this trend to destruction and they do not want to prevent the coming new global crisis, due to the American structural problems and the Europeans that follow them. The real growth of the economy ( ) is measured as follows:

$$
\dot{q}_{t}=\dot{y}_{t}-\pi_{t}
$$

For example, we can have a good real growth by having: . This 3\% real growth seems to be a desirable outcome, based on advances in technology and productivity, alternative sources of energy, embargos, imports from China and other low cost of production countries, and more efficiency, can result in certain products dropping in price over time. Then, why deflation is 
bad? Deflation helps consumers and workers, but it hurts the Treasury and the banks [increases real rate of interest; eq. (4)], and for this reason, it is firmly opposed by the Fed and ECB. Fed prefers inflation because it erases government debt, reduces the debt to GDP ratio, props up the banks, can be taxed, and lowers the real cost of capital. Thus, the Fed and the ECB are working for the banks, businesses, and the government; their policies are against people's interest.

$$
r_{t}=i_{t}-\left(-\pi_{t}\right)
$$

Consequently, Fed likes inflation and this is its objective; economic growth and employment are incidental by-products of the drive to inflation. ECB likes its power and the control that exercises on the central banks of the Euro-zone member-nations. The free market economy needs inflation and the Fed causes it. As long as deflation is a "threat", the Fed will continue with zero target rate, enormous money supply, and efforts to devaluate the dollar in order to import inflation through higher import prices. Real growth is more important than nominal growth, but it is being ignored by the Fed. It seems that the Fed will pursue this easy money (printing money) policy (pseudo-remedy) as far as possible until global investors finally lose confidence in its currency (the U.S. dollar) and in bonds denominated in dollars. Countries need publicly-owned central banks so that bankers and financiers could not use the printing of money to control the affairs of the nation. The ECB has eliminated the monetary policy from the member-nations. Then, these nations have no tools of improving their economies or get rid of their current economic crises. The EMU has unfolded as the worst nightmare for the poor European nations that made the mistake or were forced to join this monster.

Furthermore, to see the effects of monetary and the abandoned fiscal policy on our economy, we can use a vector auto-regression (VAR) with dependent variables, $u_{t}, \pi_{t}$, and $q_{t}$, and independent ones the three policy tools $\left(i_{F F_{t}}, t_{t}\right.$, and $\left.g_{t}\right)$, as follows:

$$
\begin{aligned}
& u_{t}=\alpha_{10}+A_{11}(L) u_{t-1}+A_{12}(L) \pi_{t-1}+A_{13}(L) q_{t-1}+A_{14}(L) i_{F F_{t}}+A_{15}(L) t_{t}+A_{16}(L) g_{t}+\varepsilon_{1 t} \\
& \pi_{t}=\alpha_{20}+A_{21}(L) u_{t-1}+A_{22}(L) \pi_{t-1}+A_{23}(L) q_{t-1}+A_{24}(L) i_{F F_{t}}+A_{25}(L) t_{t}+A_{26}(L) g_{t}+\varepsilon_{2 t} \\
& q_{t}=\alpha_{30}+A_{31}(L) u_{t-1}+A_{32}(L) \pi_{t-1}+A_{33}(L) q_{t-1}+A_{34}(L) i_{F F_{t}}+A_{35}(L) t_{t}+A_{36}(L) g_{t}+\varepsilon_{3 t}
\end{aligned}
$$

Where, $u_{t}=$ unemployment rate, $i_{F F_{t}}=$ federal funds rate, $t_{t}=\ln T_{t}=$ tax or government revenue, and $g_{t}=\ln G_{t}=$ government spending.

The estimation of the above VAR, eq. (5), will tell us the effectiveness of the two public policies, monetary and fiscal. This current enormous liquidity is money that sits in banks as excess reserves and does not produce inflation. Inflation appears only if consumers and businesses borrow and spend these reserves as printed money. Also, unemployment and low growth keep prices low, too. Table 1 gives the empirical results of eq. (5) and shows that pure monetary policy is not effective; a mixed public policy (fiscal and monetary) is needed to improve the economies.

\section{CONCLUSION}

Lastly, the U.S. economy has two major problems; overconsumption (underproduction, waste of resources, and outsourcing) and lack of savings (dis-saving and borrowing or spendthrift). The European economies have three major problems: common currency, lack of domestic public policies, and loss of national sovereignty. These cause current account deficits and 
capital account surpluses, which devaluated the U.S. dollar (over valuated the euro) and affected the financial markets, the interest rates, the national debt, the oil prices, the inflation, the competitiveness, the growth and employment, and the social welfare of the nations. We must learn that we cannot live beyond our means indefinitely. Actually, there is a vicious cycle in the economy, due to the wrong public policies. This latest crisis started with deregulations, integrations, globalization, enormous debts, corruptions, deterioration of human values, with high energy prices; it continued with a deteriorating housing sector, it followed with an illfunctioning financial market, it reached a slowing consumer and business spending, and it ended to a severe recession (the first depression of the 21st century).

Table 1: The VAR Estimation of Public Policy Effectiveness: Eq. (5)

\begin{tabular}{|c|c|c|c|}
\hline Variables & $u_{t}$ & $p_{t}$ & $q_{t}$ \\
\hline $\mathrm{C}$ & $\begin{array}{l}-0.658 \\
(1.324)\end{array}$ & $\begin{array}{l}-0.011 \\
(0.020)\end{array}$ & $\begin{array}{l}0.126^{* * *} \\
(0.181)\end{array}$ \\
\hline$u_{t-1}$ & $\begin{array}{l}0.969^{* * *} \\
(0.038)\end{array}$ & $\begin{array}{c}0.001 \\
(0.001)\end{array}$ & $\begin{array}{l}-0.003^{* * *} \\
(0.001)\end{array}$ \\
\hline$u_{t-2}$ & $\begin{array}{l}-0.013 \\
(0.037)\end{array}$ & $\begin{array}{l}-0.001 \\
(0.001)\end{array}$ & $\begin{array}{l}0.004^{* * *} \\
(0.002)\end{array}$ \\
\hline$p_{t-1}$ & $\begin{array}{l}4.548^{* *} \\
(2.329)\end{array}$ & $\begin{array}{l}1.334^{* * *} \\
(0.036)\end{array}$ & $\begin{array}{l}-0.057 \\
(0.063)\end{array}$ \\
\hline$p_{t-2}$ & $\begin{array}{l}-4.195^{* *} \\
(2.321)\end{array}$ & $\begin{array}{l}-0.339^{* * *} \\
(0.036)\end{array}$ & $\begin{array}{c}0.043 \\
(0.062)\end{array}$ \\
\hline$q_{t-1}$ & $\begin{array}{l}-4.721^{* * *} \\
(1.152)\end{array}$ & $\begin{array}{l}-0.027 \\
(0.018)\end{array}$ & $\begin{array}{l}0.847^{* * *} \\
(0.031)\end{array}$ \\
\hline$q_{t-2}$ & $\begin{array}{l}4.848^{* * *} \\
(1.133)\end{array}$ & $\begin{array}{c}0.029 \\
(0.017)\end{array}$ & $\begin{array}{l}0.133^{* * *} \\
(0.030)\end{array}$ \\
\hline$i_{F F_{t}}$ & $\begin{array}{l}-0.060^{* * *} \\
(0.013)\end{array}$ & $\begin{array}{c}0.001^{* *} \\
(0.001)\end{array}$ & $\begin{array}{l}-0.001 \\
(0.001)\end{array}$ \\
\hline$i_{F F_{t-1}}$ & $\begin{array}{l}0.070^{* * *} \\
(0.014)\end{array}$ & $\begin{array}{l}-0.001 \\
(0.001)\end{array}$ & $\begin{array}{l}-0.001 \\
(0.001)\end{array}$ \\
\hline$t_{t}$ & $\begin{array}{l}-3.141^{* * *} \\
(0.498)\end{array}$ & $\begin{array}{c}0.009 \\
(0.008)\end{array}$ & $\begin{array}{l}0.206^{* * *} \\
(0.013)\end{array}$ \\
\hline$t_{t-1}$ & $\begin{array}{l}2.118^{* * *} \\
(0.513)\end{array}$ & $\begin{array}{l}-0.010 \\
(0.008)\end{array}$ & $\begin{array}{l}-0.178^{* * *} \\
(0.014)\end{array}$ \\
\hline$g_{t}$ & $\begin{array}{l}1.996^{* *} \\
(0.706)\end{array}$ & $\begin{array}{c}0.001 \\
(0.011)\end{array}$ & $\begin{array}{l}0.134^{* * *} \\
(0.019)\end{array}$ \\
\hline$g_{t-1}$ & $\begin{array}{l}-1.252^{*} \\
(0.712)\end{array}$ & $\begin{array}{c}0.004 \\
(0.011)\end{array}$ & $\begin{array}{l}-0.145^{\text {*** }} \\
(0.019)\end{array}$ \\
\hline$R^{2}$ & 0.988 & 0.999 & 0.999 \\
\hline$S S R$ & 21.908 & 0.005 & 0.016 \\
\hline$F$ & 4774.112 & 4603553 & 778834.6 \\
\hline$N$ & 713 & 713 & 713 \\
\hline
\end{tabular}

Note: $* * *=$ significant at the $1 \%$ level, $* *=$ significant at the $5 \%$ level, and $*=$ significant at the 10\% level. Source: Economagic.com.

In addition, Sachs [7] said that "the United States should approach its foreign policy using 'sustainable-development logic' rather than relying on 'militarized, us-versus-them, extremistfundamentalism logic'”. European nations cannot create conflicts among nations (i.e., Imia in Greece) to sell their weapons by lending money to the poor nations to buy their military 
equipment and improve the manufacturing of the corrupted and unhesitating nationproducers and their economic growth, plus the bribery and crimes that they generate in different governments. Without an investment in sustainable development, without an increase in domestic production and reduction in imports, the U.S. will lose the competitiveness race, as it has happened with the Euro-zone member-nations with the overvalued common currency. Even today (in 2015), the U.S. economic data are very disappointing. The European ones are catastrophic. The economies need a mixed expansionary economic policy (fiscal and monetary). The neo-liberal policies are against this policy and people and nations are in devastation. The global uncertainty, the deregulation of financial markets, the integration of unequal and different nations, the sell-offs of the SOEs, the private monopolists (no one respects the anti-trust laws anymore), the corruption in business and politics (corporations do not pay taxes), the illegal migration, and the other domestic problems, due to globalization and integration are going to change our economic system (many economic laws do not hold anymore and we have to bail out all these untrustworthy businesses). The only prediction that we can do for the future, after the current worst global recession and the European debt crises and depressions, is that this new economic system, "globonomics", will be the last in our socio-economic history, except if we will decide to go back to a value oriented system.

Finally, these corrupted people in financial markets and institutions (the originators of the crisis) need some knowledge in value-oriented welfare economics and business ethics. The current crisis was not an economic one, but a moral, ethical, social, spiritual, educational, and political crisis, which was expected by every prudent person after all these mistakes that were made since 1960s. President Obama proposed to amend the law to require the Fed to get Treasury secretary's written approval before exercising its authority to lend to nearly anyone in "unusual and exigent circumstances". But, loss of confidence in the global financial system can rarely be restored. Very likely, a new system will be needed, with a new humane foundation that can engender new confidence. We wait to see. But Janet Yellen reminded to Congress on March 4, 2015 that Fed is independent. We have to educate and awaken the citizens so they could become active citizens and go back to their indigenous traditional values, otherwise there will be no hope.

\section{References}

1. Bullard, James, Christopher J. Neely, and David C. Wheelock (2009), "Systemic Risk and the

2. Financial Crisis: A Primer", Review, Federal Reserve Bank of St. Louis, Vol. 91, No. 5, September/October, pp. 403-417.

3. Kallianiotis, John N. (2013), International Financial Transactions and Exchange Rates: Trade, Investment, and Parities, New York, N.Y., U.S.A.: Palgrave MacMillan.

4. Kallianiotis, Ioannis N. (2007a), “Economic Fundamentals, Expediency, or Naïve Speculation

5. Caused the Euro's Overvaluation", unpublished manuscript, University of Scranton, November, pages 44.

6. Kallianiotis, Ioannis N. (2007b), "Macroeconomic Shocks and Public Policy Effectiveness in

7. Open Economies: U.S.A. and European Union", 2007 Conference Proceedings of NBEA, Central Connecticut State University, New Britain, CT, November 8-9, pp. 164-167.

8. Rickards, James (2014), the Death of Money: The Coming Collapse of the International Monetary System, New York, N.Y.: Portfolio/Penguin.

9. Sack, Brian (1998), "Does the Fed Act Gradually? A VAR Analysis", Finance and Economics 
10. Discussion Series, 1998-17, Board of Governors of the Federal Reserve System.

11. Sachs, Jeffrey (2008), "Common Wealth: Economics for a Crowded Planet", Keynote Address at Harvard University, Alumni Quarterly Colloquy, summer, pp. 2-5.

12. Sposi, Michael and Valerie Grossman (2014), "Deindustrialization Redeploys Workers to 13. Growing Service Sector", Economic Letter, Dallas Fed, Vol. 9, No. 11, September, pp. 1-4. 14. Stiglitz, Joseph E. (2002), Globalization and its Discontents, New York: W.W. Norton \& 15. Company.

16. Wessel, David (2009), In Fed we Trust, Crown Business, New York, N.Y., U.S.A.

17. Williamson, Stephen D. (2014), "Monetary Policy in the United States: A Brave New World?", Review, Federal Reserve Bank of St. Louis, Vol. 96, No. 2, pp. 111-121.

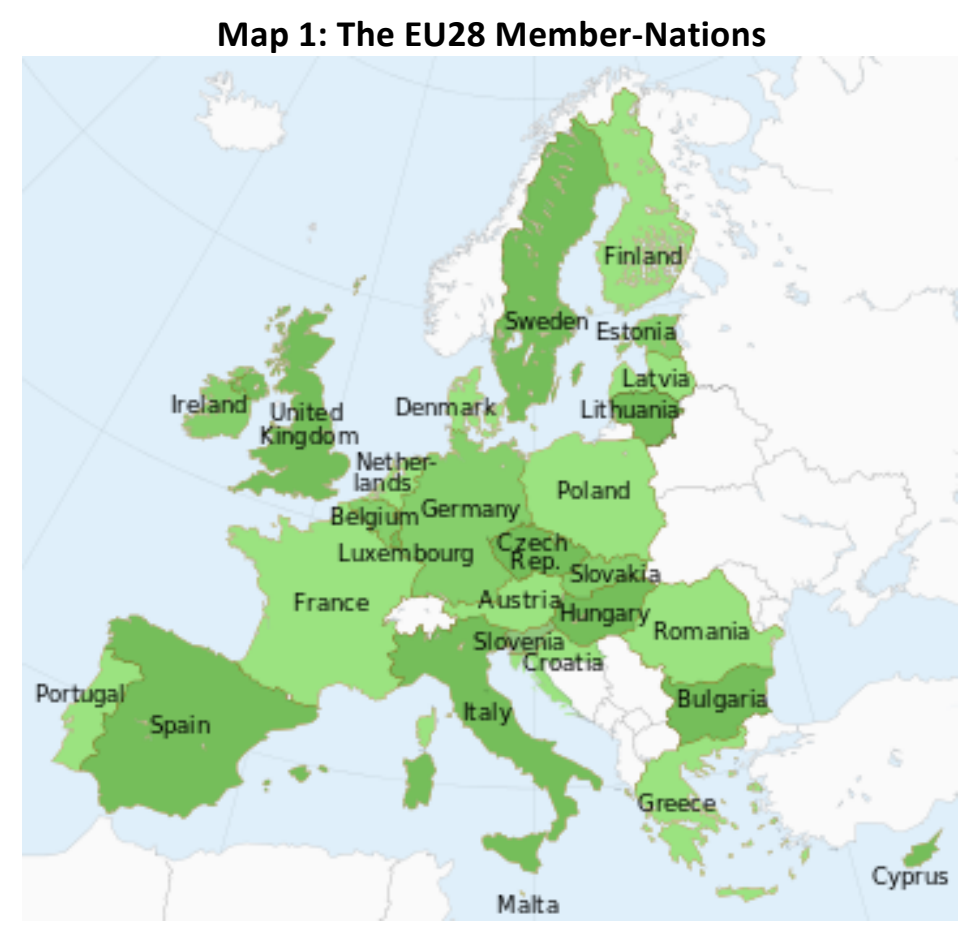

Note: Ireland, United Kingdom, France, Netherlands, Germany, Denmark, Poland, Lithuania, Latvia, Estonia, Finland, Sweden, Czech Republic, Austria, Hungary, Romania, Bulgaria, Greece, Slovakia, Slovenia, Croatia, Italy, Belgium, Luxembourg, Portugal, Spain, Malta, Cyprus. 